\title{
EVALUATION OF LANGUAGE POLICY IN LITHUANIA
}

\author{
Laima Kalėdienè \\ Institute of the Lithuanian Language
}

\begin{abstract}
In order to assess whether the language policy implemented in Lithuania corresponds to the expectations of the language users, they were asked to provide their opinion as part of the sociolinguistic survey Cities and Languages. The total reluctance to learn languages was rather surprising: only one in five residents of cities expressed a desire to learn various languages. The fact that $14 \%$ of very young people consider themselves first and foremost citizens of the world and Europeans can only be seen as a manifestation of globalisation. The most surprising result of this survey is that half of all respondents would like their children to attend bilingual i.e. Lithuanian/English schools. Separate language policies are developed for the languages used in Lithuania. A common integrated programme which contains a forecast of the prospects of all languages more actively used in Lithuania and a vision on an integral language policy is required.
\end{abstract}

Keywords: language policy, sociolinguistic survey, bilingual education, educational policy, language status, state language, language of national minority

\section{Introduction}

Lithuanian received its status as a state language on 18 November 1988. The restoration of the constitutional rights for the language broadened its functions in public life and accelerated the preparation and implementation of legal acts regulating the use of the language in various fields of activity. In Lithuania, where the national majority is $84 \%$, the language has State Language status. Lithuanian citizenship legislation was one of the most liberal and democratic laws in Eastern Europe, and knowledge of the language soon became the norm in daily life.

In order to have a chance to appeal to the facts, the project Language usage and national identity in urban areas of Lithuania 
(discussed hereinafter) was initiated. The results of this representative sociolinguistic public survey forced a reconsideration of Lithuanian language policy once again, although the website of the State Commission on the Lithuanian Language contains only Lithuanian (there denominated as the State Language) Language Policy Guidelines: Concerning the State Language Policy Guidelines for the period 2009-2013 ${ }^{1}$. The use of Russian, Polish and other languages is regulated by the Law on Ethnic Minorities of the Republic of Lithuania ${ }^{2}$, Articles 4 and 5 whereof often contain ambiguities. The perspective of the role of English as an international language is one of the most important questions in the subject of language policy. Notwithstanding this, the spread of English in the public domain, and in addition the Law on the State Language of the Republic of Lithuania ${ }^{3}$, is somewhat impeded by the Law on Consumer Protection of the Republic of Lithuania $^{4}$, and indirectly slowed by the Law on Term Bank of the Republic of Lithuania 5 .

The use and teaching of languages in the educational system, in addition to the corresponding laws on education and science, is directly regulated by orders of the Minister of Education and Science, and in higher education institutions these aspects are managed by orders of rectors and deans. Therefore each language has its own department, laws and guidelines, and it is sometimes the case that the use of one language is not sufficient for one person. Should this be how the policy concerning the use of all languages used in Lithuania is modelled? Hence the question on whether Lithuania needs to reconsider its language policy remains open.

Jacques Leclerc from the University of Laval in Canada attempted to systematise and compare language policies throughout the world. In 1988 he started accumulating documents regulating language policies in various countries, translated them into French, classified them and in 1999 published on the Internet $^{6}$ the documents regulating language policy in 470 different countries and regions. In 2008 an analysis of language policies

\footnotetext{
${ }^{1}$ See <http://www.vlkk.lt/lit/10110>. Accessed October 25, 2009.

${ }^{2}$ Official Gazette, 1989, no. 34-485.

${ }^{3}$ Same reference, 1995 , no. 15-344; 2002, no. 68-2760.

${ }^{4}$ Same reference, 2007 , no. 12-488.

${ }^{5}$ Same reference, 2004, no. 7-129.

${ }^{6}$ See $<$ http://www.tlfq.ulaval.ca/axl/index.html $>$. Accessed October 30, 2009.
} 
of these countries was performed ${ }^{7}$. Lithuanian language policy therein is referred to as a policy of discriminating legal status: the state language is granted more rights than other recognised languages. We are also referred to as representatives of a policy supporting an official language which is considered exclusive in respect of languages of national minorities. It is noted that defensive purism, or "language protectionism", is characteristic to Lithuanians. There are almost no differences in Lithuanian language policy compared to those of our neighbours with similar histories i.e. Latvia and Estonia (we are usually likewise classified in the same groups and similarly described). Unfortunately, this treasure trove of knowledge on languages contains no answer regarding the quality of the language policy implemented in Lithuania.

\section{Public opinion on the use of languages}

In order to assess whether the language policy implemented in Lithuania corresponds to the expectations of language users, they were asked to provide their opinions during a sociolinguistic survey ${ }^{8}$; applying the qualitative sociology method (multi-stage probability sample) ${ }^{9}, 2037$ residents aged 15-74 of

\footnotetext{
7 The link to Lithuania: <http://www.tlfq.ulaval.ca/axl/europe/lituanie.htm>. Accessed October 30, 2009.

${ }^{8}$ During the period 2007-2009, a project supported by the Lithuanian State Science and Studies Foundation entitled The use of languages and national identities in the cities of Lithuania (Cities and languages) was carried out $(<\mathrm{http}: / /$ projektai.vu.lt/miestaiirkalbos $>$. Accessed October 08, 2009). Project Supervisor Dr. Meilute Ramonienė and scientists from Vilnius University, Vytautas Magnus University and Klaipeda University and the Institute of the Lithuanian Language participated in the project.

${ }^{9}$ A lot of recognised sociology scientists criticise the academic significance of public opinion surveys and even tend to question the existence of public opinion (Blumer 1969: 197-199). The main argument they have is that social knowledge is a complicated phenomenon, depending on the individual's status and his or her social relations in society, therefore it is impossible to perform its mechanic calculation. It could often be the case that the respondent, because of his or her social status, does not know or "borrows" from his or her friend, neighbours and media. Therefore it is held that surveys better reflect the emotional and stereotypical reaction of people rather than a well-considered opinion. Roger Hood also notes that it is important to separate public approval from the opinion of well-informed people: public surveys may be invalid (1989: 150-158).
} 
three Lithuanian cities - Vilnius, Kaunas and Klaipeda - were interviewed. The sample was prepared in a way that ensured that each resident of Vilnius and Klaipeda to be surveyed was identical. A total of 64 questions was presented during the interviews in the respondents' homes, where the following information was to be gleaned: the ethnic background of the respondent's parents and the ethnic background of their families; their national and local identity; their mother tongue and non-mother tongue(s); their levels of use and knowledge; the particulars of the languages used in the public and private domains; the languages taught and available at the schools of the respondents and their children; and the use of dialects and assessment.

One of the least expected results was the fact that $8 \%$ of respondents indicated that they had not one (as is common) but two mother tongues: half of these respondents nominated both Lithuanian and Russian. All of these respondents were from mixed families. When asked what the level of their mother tongue knowledge was, most of the respondents, particularly Lithuanians and Russians, stated that their language skills were good (only $5 \%$ of Lithuanians and $4 \%$ of Russians thought their written language skills were average). $7 \%$ of Poles also considered their written language skills to be average, and as many believed that their written Polish skills were very bad. Approximately $10 \%$ of Poles stated that not only were their reading skills not good, but the same could also be said of their speaking skills. However, $33 \%$ of the representatives of other nationalities indicated that their mother tongue written skills were not good, and $25 \%$ said this was equally true of their reading skills. Furthermore, $12 \%$ of the respondents indicated that they even had difficulties speaking their mother tongue.

Although it was anticipated that all Lithuanian residents would have fairly good Lithuanian and Russian language skills, it had not been anticipated that only $1 \%$ of respondents would indicate no knowledge whatsoever of Lithuanian. It was expected that more than $3 \%$ of respondents would indicate no knowledge of Russian. However, 42\% had no knowledge of English, only a few had French language skills, and $75 \%$ of all respondents would not be able to communicate in German.

In addition, the total reluctance to learn languages was rather surprising: only one in every five residents of the cities surveyed expressed a desire to learn other languages. This fifth of 
the respondents ${ }^{10}$ is already learning or intends to learn English. Non-Lithuanians disclosed that they most often study Lithuanian privately, and in one form or another $27 \%$ of all respondents are learning a language by reading, surfing the Internet and watching television. The majority of them complained that they found it difficult to learn Lithuanian. The wish to talk to Lithuanians was indicated as the most significant motive for learning the language (71\%), while more than $33 \%$ studied the language out of respect for the country and $29 \%$ because of better work prospects.

Almost all of the respondents stated that their mother tongue was the most beautiful and most common of all languages when asked to assess it. Lithuanian is considered to be the most required in Lithuania because it is the most appropriate language for use in business, higher education sectors and public life. English was almost unanimously indicated as the most prestigious language. As was expected, young respondents had a better knowledge of Lithuanian and English: only 1\% of non-Lithuanians stated that they never wrote in Lithuanian. Older respondents more often attempted to communicate in Russian than English, while with young people the situation was vice versa.

The impact of globalisation is more strongly felt by youth: the fact that $14 \%$ of young people consider themselves citizens of the world and Europeans first and foremost can only be seen as a manifestation of globalisation; they consider national identity as not being very important to them. However, they do consider Lithuanian to be their mother tongue.

The most surprising result of this survey is that $50 \%$ of the respondents would like their children to attend bilingual i.e. Lithuanian/English schools. This is most desired by younger respondents.

\section{Educational policy on the choice of languages}

One of the central problems disclosed during the survey is the choice of teaching language(s) in order to achieve more effective communication among members of the public. This is not only widely discussed in society, but must also be addressed in

\footnotetext{
${ }^{10}$ Since the youngest respondents were fifteen years of age, the highest proportion of respondents "learning languages" were undoubtedly students from secondary schools or in higher education.
} 
language policy, and especially in the education planning sector. Some members of society feel that the main teaching language in Lithuania should be Lithuanian, but a lot of people are of the opinion that the teaching process could use various languages, and the importance of English is emphasised.

The significance of English and its direct impact on national languages has been steadily increasing around the world. Its impact on the status of national languages is also becoming more pronounced (Liddicoat and Baldauf 2008). Even though Lithuanian is widely used in Lithuania, the global impact of English manifests itself here, too, because, the prestige of English is more important to a lot of people than the prestige of their own language. Consequently, the Lithuanian ecolinguistic system is also under threat. ${ }^{11}$

Analysis of the situation of secondary education as part of the current education system showed that although social demand for the teaching of English was previously evident (during the school year 2006-2007, 86\% of pupils in comprehensive schools studied English, while 47\% learned Russian, 18\% German and 3\% French; therefore, on average, pupils in secondary education programmes studied 1.6 foreign languages during the school year ${ }^{12}$ ). However, Lithuanian educational policy was not shaped in such a way that the needs of its citizens were satisfied. The early English language teaching programme introduced in 2009 in primary schools (starting from the second grade) is unlikely to be successful due to the shortage of English teachers. This in turn is due to well-qualified people not being willing to work in schools because of the low salaries.

English has a diverse impact on Lithuanian: the poorer the knowledge of English, the less predictive the impact and interference of the language. The official language policy in Lithuania has assumed a defensive position and we are not prepared to

\footnotetext{
${ }^{11}$ Ecolinguistics emerged in the last decade of the last century. This is sociolinguistics, the goal of which is research on the functioning of language or languages in society, transferred into another dimension: the functioning of both the languages and the society itself are researched in parallel. Michael Halliday is considered the pioneer of research into the ecological context of languages. In 1990 he published the article New Ways of Meaning: the Challenge to Applied Linguistics.

${ }^{12}$ See $<$ http:// www.smm.lt/svietimo_bukle/docs/apzvalgos/Svietimas_regionuose_2007.pdf $>$. Accessed September 21, 2009.
} 
foster and develop Lithuanian in new circumstances: other countries have implemented alternative integral teaching using two or more languages during the same lesson, and this will soon happen in Lithuania.

That language status is significant to its future fate is also confirmed by the fact that the overall majority of non-Lithuanian citizens have learnt Lithuanian as a foreign language. A notably positive attitude towards the need to know Lithuanian as the state language can be explained in much the same way as the attitude towards knowledge of English.

To summarise the above, it may be said that Lithuanian society is no different to societies of other European countries, because people understand the significance of English in their lives, as well as in the lives of their children, as the leading language of communication in present-day Europe and throughout most of the world. Most of the respondents who would prefer bilingual schools do so based on intuition, without having heard of the newest tendencies and fashions in language teaching (cf. Ferguson 2006).

\section{How do Poles and Russians in Lithuania differ from Lithuanians?}

\subsection{Identity}

The answers to the question as to how the respondents define their identity enable an analysis of the links between language, nationality, origin and identity. The respondents were provided with six answers to choose from: I feel Lithuanian/ Russian/Polish/European/I am a citizen of the world/ your own answer (or no answer).

Most Poles feel Polish (73\%); 6\% identify themselves with Lithuanians, 3\% with Russians, 7\% feel European and 6\% consider themselves citizens of the world. It is clear that the answers of those who nominated Polish as their mother tongue and the answers of the Poles are similar, although the former feel more Polish (79\%) and Lithuanian (8\%) and fewer of them feel European $(4 \%)$. Only $7 \%$ of Poles feel they are Europeans or citizens of the world $(6 \%)$, whereas more feel they are Russians of the city of Vilnius (10\% and $7 \%$ accordingly), but this amounts to a 
more significant percentage than that of Lithuanians residing in Vilnius (5\% and $3 \%$ accordingly).

When analysing the Polish group it becomes evident that it is mostly the older generation who identify themselves with the Poles, and the biggest number of Europeans is among the representatives of the youngest generation; citizens of the world are mainly accounted for by respondents in the 30-49 age bracket. The representatives of the older generation more often identify themselves with Lithuanians and the representatives of the youngest generation more often identify themselves with Russians. The answers show that most Poles residing in the cities surveyed feel the strongest links with the place of residence and the community of the smaller territory (city).

Concerning the Russians residing in Lithuania, it became clear that two-thirds of those participating in the survey were born in Lithuania, a quarter as second generation, with their parents also having been born in Lithuania. One third of the respondents were born abroad, predominantly in Russia or the former Soviet Union. On the one hand, it can be said that the national identity of Russians is fairly strong - the national identity of three out of four representatives of this nationality is adequate to their actual nationality. On the other hand, most residents with Russian nationality do not care about their nationality $(46 \%)$ or would not mind being called Lithuanians (74\%).

\subsection{Mother tongue}

902 people were surveyed in the Lithuanian capital Vilnius: 491 Lithuanians (54\%), 123 Russians (14\%), 162 Poles (18\%) and 115 other nationalities (13\%). The overall majority of Poles in Lithuania lives in Vilnius. Research shows that a considerable proportion of the respondents claim several languages as mother tongues: $80 \%$ (130 people) of those surveyed in Vilnius consider Polish as their mother tongue or one of their mother tongues. $72 \%$ (117 people) consider Polish only as their mother tongue, and 9\% (14 people) indicated two languages: Russian and Polish (8 people) or Lithuanian and Polish ( 5 people). $4 \%$ of the respondents (6 people) indicated three mother tongues: Russian, Lithuanian and Polish. $15 \%$ of respondents of Polish nationality ( 24 people) indicated a mother tongue other than Polish: 20 respondents (12\%) 
nominated Russian and 4 people (3\%) chose Lithuanian. As such, the tendency of young Polish people in Lithuania to choose dual Polish-Lithuanian identity is obvious: based on the material collected during the research, $12 \%$ of Poles participating in the research indicated two or three mother tongues.

All Russian residents of Lithuanian cities know their mother tongue. However, it is apparent that this situation can change. Those who did not study Russian at school can only speak and understand it aurally, but they cannot read the Cyrillic alphabet and thus can neither read nor write the language. The research indicates that Russians use their mother tongue intensively and mostly for personal needs. If the language required is for communication in society, the mother tongue can be replaced by the state language. In the local environment the use of Lithuanian becomes more common. The most intimate area - communication with God - remains closed to Lithuanian.

\subsection{Level of education}

Most of the Poles (36\%) surveyed completed general secondary education, and $30 \%$ had special secondary education. $77 \%$ of the Poles were born to families where both parents were Poles. Currently, mixed families in terms of nationality are becoming more common: only $46 \%$ of the respondents live in families where family members are of one nationality; $22 \%$ are mixed Lithuanian-Polish families and $16 \%$ are Russian-Polish families.

The respondents of Lithuanian nationality more often obtained higher education (69\% in Vilnius and Klaipeda and 81\% in Kaunas). The respondents of Russian nationality (24\%) and those who speak Russian as their mother tongue (11\%) more often indicated that they have special secondary education or higher non-university education.

\subsection{Evaluation of knowledge of Lithuanian, Russian and Polish}

An evaluation of the respondents on their knowledge of Lithuanian, Russian and Polish was carried out. The overall result of this evaluation is rather high: almost all Poles (98-99\%) 
understand Lithuanian and Russian, and 96\% understand Polish. $96 \%$ speak Lithuanian and give their knowledge a rather good evaluation: $57 \%$ answered "Yes" to the question as to whether they speak Lithuanian with an accent, 31\% answered "No" to this question and $12 \%$ indicated that it was "hard to say". The respondents indicated Russian as the language which they knew best. $64 \%$ of the people in this group did not know English. The worse evaluation of the respondents' writing skills and no knowledge of English is a consequence of the respondents' education and their age.

In all cities, Russians do not use their mother tongue for reading and writing as often as the state language. In terms of evaluating their knowledge of Lithuanian, half of the residents of Kaunas of Russian nationality assume that they speak it without an accent, while 38\% feel that they do have an accent. Most Russians notice their accent, and although those who speak with one have no particular problems in this respect, they generally feel uncomfortable among Lithuanians.

\subsection{Use of languages in public and private domains}

The distribution of the languages according to their scope of use in the public and private domains is provided below. The respondents of Polish nationality often indicate that they use all three languages (Lithuanian, Russian and Polish) on a daily basis. The Poles mostly speak Polish (71\%), although they often also speak Russian (64\%) and Lithuanian (59\%). 54\% of respondents mostly think in Polish; 34\% do so in Russian and 23\% in Lithuanian. The respondents often perform calculations using all three languages. The Poles most often pray in Polish (77\%), and this is the highest indicator of the use of this language.

Let us discuss the linguistic situation in the private domain. The Poles mostly only use Polish when speaking to the closest members of their families i.e. parents, grandparents, brothers and sisters: $77 \%$ speak Polish with their mothers, $75 \%$ with their fathers and $73 \%$ with their brothers and sisters. Spouses more often communicate in Polish (45\%) or Russian (40\%), and often the languages are alternated. It can be observed that the respondents adapt to spouses who speak other languages (now that only 
$46 \%$ of respondents live in families of one nationality; $22 \%$ are in mixed Lithuanian-Polish families and 16\% in Russian-Polish families). Only $58 \%$ of the respondents speak Polish with their children often, and only $51 \%$ communicate with their grandchildren in Polish on a regular basis. Lithuanian, in addition to Polish and Russian, is increasingly used when speaking with representatives of the younger generation: $25 \%$ often speak Lithuanian with their children and 34\% with their grandchildren.

The data collected from the survey questionnaires discloses that in the informal public domain i.e. while communicating with their neighbours, friends and acquaintances, the Poles speak all three languages; mother tongues are used therein, often being alternated.

Upon reviewing the situations of earlier public language use, certain tendencies are observed: the Poles more often read books and quarrel in Russian; they write more often, read the press, listen to the radio, watch television shows and surf the Internet in Lithuanian or Russian. The lack of popularity of the Polish media (only 19\% often watch Polish television, $12 \%$ often surf Polish Internet sites and 28\% read the Polish press) indicates that almost all information about the world is obtained in Lithuanian and Russian.

Most of the respondents of Russian nationality use their mother tongue: $75-93 \%$ of them more often use Russian for speaking, watching TV, thinking, calculating, listening to the radio, writing and reading books and newspapers. The use of Russian when quarrelling and praying appeared to be irrelevant (52\% and 48\%). Almost half of all Russian respondents do not surf the Internet, but those who do use both Russian and Lithuanian equally; the use of English is down by half.

In their daily lives Russians use two languages: their mother tongue and Lithuanian. The research indicates that Russians use Lithuanian more to satisfy their civic needs (speak, read newspapers and magazines, watch TV and calculate) and less so in order to satisfy their personal needs and for recreation (read books and listen to the radio). Russian and Lithuanian as Internet languages are used almost equally, while the use of English here is less frequent. Significantly fewer Russians think in Lithuanian (47\%) and they almost never pray in Lithuanian (only 13\%).

Furthermore, people of Russian nationality residing in cities speak not only their mother tongue but also Lithuanian in the 
private environment. The distribution is distinct: communicating with older family members (grandparents, parents, brothers/ sisters and animals) is mostly in Russian, while Lithuanian is mainly used when communicating with the younger generation (children and grandchildren). Alternation between the languages is common.

Russians mostly use Lithuanian in the public domain. They tend to use the state language (Lithuanian) in the working environment.

\subsection{Languages of schooling}

The Department of Statistics announced that at the beginning of 2008 there were $6.2 \%(208,300)$ Poles residing in Lithuania, and during the 2007-2008 school year there were 3.4\% $(16,041)$ pupils studying in Polish schools ${ }^{13}$. This indicates that parents tend to provide their children with education in the state language. $62 \%$ of the Poles surveyed studied in Polish schools, $34 \%$ in Russian schools and only $10 \%$ in Lithuanian schools. The answers to the questions on the schools the children of the respondents attend show that only $46 \%$ of the children attend Polish schools: 33\% attend Lithuanian schools and 29\% attend Russian schools.

$92 \%$ of respondents of Russian nationality in Vilnius, Klaipeda and Kaunas indicated that they attended schools where the teaching language was Russian and spoke only Russian during breaks. This means that adults attended Russian schools and the schools were indeed Russian. There were a lot of such schools during these times.

However, Russian schools in Kaunas are different from Russian schools in Vilnius and Klaipeda. Now, every fourth Russian speaking resident of Kaunas (25\%) studied/studies at schools where the teaching language is Russian, and only every fifth person (19\%) uses Russian during breaks.

The forecast for the future is somewhat different: less Russians are choosing monolingual Russian schools for their children. Russians in Vilnius and Klaipeda still want their children to be taught in their mother tongue (44\%), while only $4 \%$

\footnotetext{
${ }^{13}$ See $<$ http://www.stat.gov.lt/uploads/pdf/1_LSM_2008.pdf $>$ (p. 42, 115). Accessed August 12, 2009.
} 
of the residents of Kaunas expressed such a wish. Most Russians see a future in bilingual schools with Lithuanian as the predominant language. This is favoured by $59 \%$ of Vilnius and Klaipeda residents of Russian nationality.

Kaunas has other priorities: Russians seldom choose bilingual Lithuanian/Russian schools, more often choosing Lithuanian/English schools. Every second respondent (56\%) of Russian nationality residing in Kaunas would prefer to send their children to schools where Lithuanian and English are the teaching languages, while on in three (33\%) would like their children to be admitted to a Lithuanian/Russian school.

Nationality and mother tongue are losing their significance, and people are becoming more pragmatic. It is hard to judge from the research whether the reluctance of Russians to send their children to Russian schools correlates with the closure of such schools or whether the closure of Russian schools is forcing them to adapt to new circumstances and change their attitudes. However, it is obvious that nationality and mother tongue are no longer priority values in education.

\subsection{Foreign languages}

Among the languages known to the Russians residing in the cities of Lithuania are English, Polish and German. 44\% of the Russians indicate a good knowledge of English, and 26\% know Polish well. German was unpopular among respondents of Russian nationality, with only $12 \%$ knowing the language. French is very unpopular; there is almost no knowledge of it (just 1\%). The largest share of problems occurs due to the lack of knowledge of Lithuanian and English. The lack of knowledge of other languages is not a significant barrier on the labour market.

This minor interest in languages is reflected by the fact that only $20 \%$ of Russians learn one or more foreign languages. The overall majority of respondents $(60 \%)$ study English, while only 10\% study German and 5\% French; other foreign languages amount to $20 \%$. This is not a coincidence, because English was marked out by the respondents as the most required and prestigious language. This lack of desire to learn languages is not only characteristic of Russian nationals: it also reflects the common attitude of the residents of Lithuanian cities - language studies 
are not popular. It is considered sufficient to learn a foreign language or foreign languages at school. $77 \%$ of the respondents stated that they did not learn and were not going to start learning any languages in the immediate future. Only $23 \%$ study or plan to study foreign languages (in most cases English).

There are more Poles who understand Lithuanian than those who speak or write it, but the difference between those who understand and those who write Lithuanian is just $6 \%$. This tendency can also be observed when talking about Polish. In the case of this language, the difference amounts to $8 \%$. The respondents indicated Russian as the language which they knew best. $64 \%$ of the respondents in this group did not know English.

\subsection{Evaluation}

More than half of the Poles residing in Vilnius (56\%) mentioned that Polish was the most beautiful language to them. The language which was most required was Lithuanian (67\%). The second language after Lithuanian, according to necessity, was English, which was selected by $43 \%$ of respondents. Only $8 \%$ of Poles had the same opinion about Polish. The most common language is Russian (this being the opinion of $59 \%$ of respondents).

For a long time the opinion prevailed that Russians do not know and do not learn Lithuanian or other foreign languages and do not use them in their daily lives. Can this opinion be contradicted? The research shows that there are no Russians who maintain that knowledge of Lithuanian as the state language is irrelevant to them or that it is not essential.

To Russians, their mother tongue seems the most common and beautiful. The most required languages are Lithuanian and English, while the most prestigious language to Russians is English.

\section{Summary}

Separate language policies are developed for the languages used in Lithuania: the State Commission on the Lithuanian Language attends to Lithuanian language policy and the Department of National Minorities and Lithuanians Living Abroad under 
the Government of the Republic of Lithuania ${ }^{14}$ takes care of the Russian, Polish and Belarusian language policies as well as the language policies of other national minorities, and supervision of English is performed by the Ministry of Education and Science. A common integrated programme which contains a forecast on the prospects of all of the languages actively used in Lithuania and a vision on an integral language policy is required.

The sociolinguistic survey of the civic population aimed to reveal public opinion on sensitive issues of language policy. One of the more intense needs is that half of the respondents stated that they would like their children to attend bilingual Lithuanian/ English schools. Attention must be paid to the fact that almost half of the respondents have no knowledge of English whatsoever, although they consider this language the most prestigious. Furthermore, most respondents (especially older ones) have no intention of studying it.

The other tendency which has become more noticeable and is disturbing involves changes in resolve regarding national identity: one sixth of young people surveyed made a decision not to be Lithuanian, but to live as Europeans or citizens of the world. However, one of the most gratifying results of the survey is that almost all of the residents of the cities in Lithuania know Lithuanian. Such a result could not have been dreamt of just a couple of decades ago.

\section{Acknowledgements}

I must sincerely thank my partners in this project, Dr. Kinga Geben and Dr. Jelena Brazauskienè, for certain figures (particularly concerning Poles and Russians) they calculated, which I have checked at conferences.

\footnotetext{
${ }^{14}$ According to decision no. 634 of 10 June 2009 of the Government of the Republic of Lithuania, the Department of National Minorities and Lithuanians Living Abroad under the Government of the Republic of Lithuania was reorganised on 1 January 2010 and its rights and duties were distributed among the Ministry of Foreign Affairs (coordination of affairs of Lithuanians living abroad, including non-formal education), the Ministry of Culture (coordination of issues of national minorities) and the Ministry of Education and Science (education of Lithuanians living abroad and national minorities) (see $<\mathrm{http}$ :// www.tmid.1t>. Accessed April 21, 2010).
} 


\section{Address:}

Laima Kalèdienè

Institute of the Lithuanian Language

P. Vileišio st. 5

LT-10308, Vilnius, Lithuania

E-mail: kaledienei@gmail.com

\section{References}

Blumer, Herbert (1969) "Public opinion and public opinion polling”. In Herbert Blumer Symbolic interactionism: perspective and method, 195-208. Berkley: University of California Press.

Būdienè, Virginija et al., eds. (2008) "Švietimo būklès tyrimų apžvalga. Valstybinès švietimo' strategijos 2003-2012 metams ir Ekonominio bendradarbiavimo ir plètros organizacijos rekomendaciju Lietuvai aspektu". <www.smm.lt/svietimo_bukle/docs/.../Svietimo_bukles_apzvalga-2.pdf>. Accessed June 28, 2011.

Concerning the state language policy guidelines for the period of 2009-2013. $<\mathrm{http}: / /$ www.vlkk.1t/lit/10110>. Accessed October 25, 2009.

Department of National Minorities and Lithuanians Living Abroad under the Government of the Republic of Lithuania. <http://www.tmid.lt>. Accessed April 21, 2010.

Department of Statistics under the Government of the Republic of Lithuania. $<$ http://www.stat.gov.lt/uploads/pdf/1_LSM_2008.pdf>, (p. 42, 115). Accessed August 12, 2009.

Ferguson, Gibson (2006) Language planning and education. Edinburgh: Edinburgh University Press.

Halliday, Michael (1990) "New ways of meaning: the challenge to applied linguistics". In Alwin Fill and Peter Mühlhäusler, eds. The ecolinguistics reader, 175-202. London: Continuum.

Hood, Roger (1989) The death penalty: a world-wide perspective, 150-158. Oxford: Clarendon Press.

"Law on consumer protection of the Republic of Lithuania", Official Gazette 2007, nro. 12-488.

"Law on ethnic minorities of the Republic of Lithuania", Official Gazette 1989, nro. 34-485.

"Law on term bank of the Republic of Lithuania", Official Gazette 2004, nro. 7-129.

"Law on the state language of the Republic of Lithuania", Official Gazette 1995, nro. 15-344; 2002, nro. 68-2760. 
Liddicoat, Anthony J. and Richard B. Baldauf (2008) "Language planning in local contexts: agents, contexts and interactions". In Anthony J. Liddicoat and Richard B. Baldauf, eds. Language planning in local contexts, 3-17. Clevedon: Multilingual Matters.

Leclerc, Jacques (2007) L'aménagement linguistique dans le monde. Québec, TLFQ, Universitaté Laval. <http://www.tlfq.ulaval.ca/axl/index.html>. Accessed October 30, 2009.

Project The use of languages and national identities in the cities of Lithuania (Cities and languages). < http://projektai.vu.lt/miestaiirkalbos>. Accessed October 08, 2009.

The link to Lithuania: <http://www.tlfq.ulaval.ca/axl/europe/lituanie.htm>. Accessed October 30, 2009.

Kokkuvõte. Laima Kalèdienė: Hinnates Leedu keelepoliitikat. Et hinnata, kas Leedus rakendatav keelepoliitika vastab keelekasutajate ootustele, paluti neil avaldada oma arvamust sotsiolingvistilise uuringu „Linnad ja keeled” raames. Üsna üllatav oli üldine vastumeelsus keelte õppimise suhtes: vaid üks viiest linnaelanikust väljendas soovi õppida erinevaid keeli. Asjaolu, et 14\% väga noortest inimestest peab end eelkõige maailmakodanikuks ja eurooplaseks, saab pidada üleilmastumise ilminguks. Uuringu kõige üllatavam tulemus oli tõsiasi, et pooled vastajatest tahaksid panna oma lapsed kakskeelsesse, st leedu- ja ingliskeelsesse kooli. Leedus räägitavatele keeltele kujundatakse eraldi keelepoliitikaid. Vaja on ühtset terviklikku programmi, mis sisaldaks hinnangut kõikide Leedus aktiivsemalt kasutatavate keelte väljavaadete kohta ning nägemust terviklikust keelepoliitikast.

Võtmesõnad: keelepoliitika, sotsiolingvistiline uuring, kakskeelne haridus, hariduspoliitika, keele seisund, riigikeel ja rahvusvähemuste keel 